Global Conferences Series:

Social Sciences, Education and Humanities (GCSSSEH), Volume 2, 2019

The $2^{\text {nd }}$ International Conference on Sustainable Development \& Multi-Ethnic Society

DOI: https://doi.org/10.32698/GCS.0179

\title{
The Diversity of Teaching Creativity towards Enhancing Soft Skills for History Students
}

\author{
Sulaiman Sarabani ${ }^{1}$, Mohd Mahzan Awang ${ }^{1}$, Abdul Razaq Ahmad ${ }^{1}$, Anuar Ahmad ${ }^{1}$ \\ \& Asmahani Muhthar ${ }^{1}$ \\ ${ }^{1}$ Faculty of Education, MALAYSIA \\ E-mail: sulaimansarabani@gmail.com
}

\begin{abstract}
At this point we often hear the difficulty of university students get jobs. Job opportunities that have too much competition. In other words, after learning to be at the secondary school level and university, it seems that the students are less executable and can not create a job opportunity that can provide lucrative income. Employers in jobs rarely employ local university products, or secondary school students with SPM and STPM certificates. The employer prefers to employ graduates from overseas universities. Why this happens, of course, because the field and approval are the same. Surely there is something to see what is necessary for school students and local universities that need to be given a major focus by educators. Areas that need to be noted are soft skills or soft skill. How we need to implement this Soft Skills to students especially historical students. One way to apply soft skill or soft skills to historical students with a variety of teaching and learning. The diversity of teaching and learning methods will certainly improve the skills of soft or Soft Skills of historical students. The various creativity of teaching and learning used by educators such as teachers and lecturers are able to produce students who are able to dominate soft skill into the future of students who are able to compete in the employment market and able to generate their own income in the local and international markets. What is the diversity of teaching and learning and soft skill will be discussed deeper in this paper.
\end{abstract}

Keywords: Soft Skill, university graduates, Occupational, diversity, teaching and learning

\section{Introduction}

This paper was produced for research studies, entitled to various creative teaching and learning towards improving the soft skills student history. According to the Dictionary of the fourth edition of a variety defined variants of a mixture of various kinds; 2. (consisting) of various varieties, diversity of folklore material. What is creativity ? Creativity is creating a new link. The House Dictionary (1993) gives the meaning of creativity as a ability (ability) to create creativity, creativity.There are several opinions that submitted by experts on creativity. According to Viktor Lowenfeld (1975), creativity is a natural instinct (Instinct) since the birth belongs to everyone. According to June King mcfee, the creativity is the ability to create new symbology and ideas, to 
update existing symbology. According to guilford See creative thinking as a flexible thought, last from old thought shackles and trying to find a new direction of thought and direction. According to Jones (1972) and Mazlan Mohamad (1994), all men were born with potential for creative nature; and with the availability of appropriate thinking and techniques, then the potential. This can be known, nurtured and measured. This paper will talk about the theories of teaching and learning and what is soft skills and will relate it to each other for the benefit of this scientific study dedicated to students History to improve the Soft Skills student history. The concept of theory is a rough principle which is the basis of forming a knowledge. Theory is also a summary of the existing knowledge that guides to conduct research and get new information.On basically, the theory the current teaching and learning theory can be classified into four denominations that Main, namely Behavioris, Cognitive, Social and Humanis.

\section{Theory and Model}

The theory of the Behavioris, introduced by Ivan Pavlov and was developed by Thorndike and Skinner, argued that learning was related With behavioral changes. Their learning theories are mainly produced from Tests and observations on animals such as dogs, rats, cats and birds in the laboratory. They concentrate on ' stimulation ' and 'reactions'yang produce behavioural changes.In general theory Behavioris state that teaching and learning will affect all students ' deeds or behaviours whether good or other wise. This theory also explains student's behavior can be noted, controlled and predict able. Based on This theory we can apply the appropriate Soft Skills to the historical students after educators understand this behavioris theory .

The cognitive sect theory also holds that teaching and learning is an internal process that occurs in the sense of Fikran, and can not be observed directly rather than behavior practice. Cognitive psychology experts such as Bruner and Piaget focus their studies on various types of learning in problem solving processes and resourcefulness according to various age ratings and abilities student. Their learning theories are based on learning methods such as logic, problem solving, Discovery and categorising. According to this cognitive theory, humans have cognitive structures, and during the learning process, the brain will compile all the information in memory.

According to the Social school theory, it suggests a theory of learning by combining the behaviotic sect theory together with the cognitive sect.This theory is also known as the Model treatment theory. According to Albert bandura, a figure of the social sect stated that the learning process will be performed more effectively using the 'modeling' approach. He explained again that the attention aspect of the students to what the teacher has expressed or done and also the aspect of impersonation by the student will be able to give an optimum impression to the understanding of students.

According to the Humanis, the theory of human learning is dependent on the emotional and her feelings. A member of this, Carl Rogers thinks that each individual has a different way of learning with other individuals. By it, strategy and the approach in teaching and learning process should be planned and arranged according to the needs and emotional development of the student. He also explained that each individual has the potential and desire to achieve self-excellence. Hence, teachers should take care of their students and to give guidance so that their potential can be extended to the optimum level.

According to its teaching and learning Model Robert Glazer, submit a teaching Model by dividing the teaching process into four main components, namely the objective of teaching, students ' existing knowledge , teaching and evaluation methods.He also emphasized student feedback as an important aspect in the teaching and learning process.In Accordance with the objective teaching should be determined according to the existing knowledge of students. Then, the method teaching should be selected based on students ' existing teaching and knowledge objectives. Subsequently, the assessment should be carried out for all teaching processes with the aim of detecting weakness, so that teachers can modify the process teaching,to enhance the effectiveness of teaching in the future. In conclusion, the teaching Model Robert Glaser was built on the concept of teaching as a process that emphasised the teaching measures of planning, evaluation, assessment and feedback.

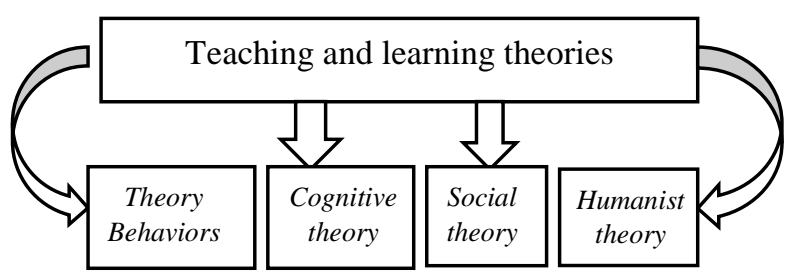

Figure 1: Theories of teaching and learning 
According to the theory of the Sim model, the teaching process is through interaction between several elements namely teachers, students, subjects and objectives. This Model is built on a concept of teaching as a field of communication,that is interaction between teachers and pupils with the objective and lesson in a particular environment.Based on Models This, the objective studies should be determined by explisit and by abilities pupils. What of distinguish Model this with Model Glaseris Sim Model stressed Relationship of Good between teacher with pupils so that poses Interaction sofhealthily and ambiance lessonand learning of effective.Model this also give emphasis on of Elements Shopping Area as Circumstance Socioeconomicand Cultures Students '. In conclusion, by these, interactions between teachers,students', objectives, content Lesson and Shopping Area be able to created with effective.Next, effectiveness processes lesson willbe able to reached to level optimal.

According to the model theory Taba also emphasized the preparation of teaching materials in a suitable system that can improve student thinking skills. The preparation of information in the teaching and learning process is a priority in this model.This Model explains that one student performs cognitive operations on the teaching material or the selection of a concept should be done through four ranks as follows;develop data or facts by careful characteristics of equations and difference,and weld facts into categories and label it,make a generalization or conclusion of the relationships between those categories,and apply the acquired generalization.His formulation, with refer to the model this, Teacher can design the teaching by dividing the topic into generalization, conceptand useful facts to determine the appropriate teaching methods.

According to the direct instruction Model is a teaching model aimed at helping students learn the knowledge or basic skills that can be taught in a step-bystep manner. This Model is also known as ' Training Model ' and ' Active teaching Model '. This Model is specially designed to stimulate students ' learning related to procedural knowledge ( knowledge procedures) which requires either basic or packaged skills as well as related Knowledge requiring step-by-step teaching. This Model emphasizes the aspect of student's observation of what the teacher shows before the student is re-doing.

According to the inquiry Model, the lesson covers all the questionnaires to obtain answers or conclusions from questions, or from problems submitted. This questionnaire requires students to identify problematic questions, form hypothesis, plan research activities, conduct research , and to find the answers and making solutions.In teaching and learning activities, there are two types of techniques Inquiry 'Inquiry ' and 'Inquiry open '.Inquiry requires students ' to carry out all research processes.Inquiry This type is suitable for primary and secondary school. In an open inquiry, students are not given any guidance. All research processes are conducted by their own students. Therefore , it is suitable to be implemented at a higher level of study such as university. In conclusion, the inquiry model is useful to obtain new information and knowledge in various fields especially in education.

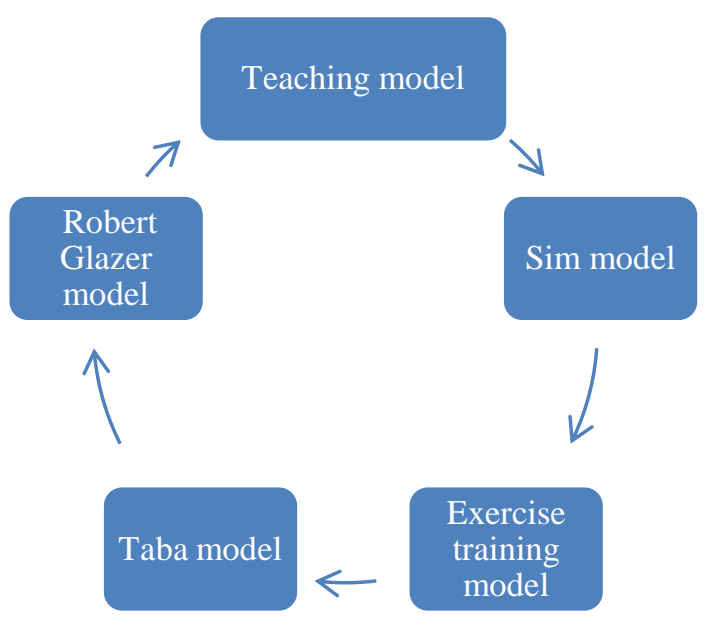

DIAGRAM 2: Teaching and learning concept Model

A good teacher's understanding of these theories and teaching and learning models makes it easy for teachers to build appropriate teaching materials to improve the Soft Skills of the history students especially in school history teachers.

Soft skills or even soft and well-known skills are the main focus that needs to be enhanced in the teaching and learning process delivered by a educator. Soft Skills It is an important element that needs to be mastered by every student in the school especially historical students besides academic achievement. The mastery of Soft Skill is important to ensure that every historical student becomes a skilled human capital to communicate, solve problems, innovate and be competitive. Soft skill skills are needed to be a more flexible, initiative and capable human capital to solve a creative one. There by making the human capital a highquality country that can dominate Soft Skills and have academic qualification its main historical students. Schools and universities are educational institutions that 
serve as a place to produce human capital with high quality human capital characteristics. The application and construction of Soft Skills is required to produce quality human capital. As a teacher or educator plays an important role in ensuring the application and construction of Soft Skills on students occurs as well as the mastery of knowledge learned. Application and Construction Soft Skill among the historical students from the school bench will be able to produce the human capital required by the national education philosophy. According to Uminnadiha (2011) The success and effectiveness of an educational institution in adopting and developing a soft skill in students is highly dependent on the skills of teachers To implement quality teaching and learning process .Schools and universities need to ensure that the students do not only have a quality academic qualification but provided with Soft Skill that are needed in the employment market. Quality historical students from academic and soft skill will have good human capital value and can assist in future development of the country. They will be citizens who have Soft Skill that is needed to live a better life. Therefore, schools and teachers need to have a holistic approach to produce high quality historical students by emphasizing the development of knowledge, skills, intellectual capital, progressive attitude and ethics and high morale. Interest Soft Skill be seen in the education system in the West. Their educational practitioners saw that Soft Skill was one of the aspects to be given appropriate attention and it was often a subject of study. This is due to a claim by an employer who assumes that Soft Skills is necessary and should be in know and is owned by a new employee. With Soft Skills and its own academic qualification will make them competent and highly capable workers in the world of work. For that the curriculum of the education must emphasize the aspect of Soft Skill. The Western practitioners consider Soft Skills that is an important aspect to produce and provide students with efficient, competent and further contributions to Country. According to Noraini (2011) Education through the teaching and learning process is an effort to produce peopling who Knowledge able, Personality as well as high human capital, belonging, responsible, communicating and able to receive challenges. Therefore, to ensure that this effort is a reality, it is the responsibility of the school and teachers to implement the soft skill skills needed in life while ensuring that students dominate their knowledge Learned.

In the west and some other countries, they use different terms to visualize and explain the Maxus associated with Soft skill or soft skills or Generic skills.
The terms used are mainly related to the skills of personnel, attitudes, habits and behaviors, how to communicate, solve problems and the skills of making decision and managing an organization. According to Azam (2007) example, the term is core skills, soft skill, basic skills, essential Skills, Key Qualifications and so, however, there is no specific definition given to these terms. According to Azam (2007), it has concluded that Soft skill consists of three elements which are skills, efficiency, and competence. Skills can be construed as efficiency and reliability to do something while efficiency is the ability or ability to do things quickly and properly, skilled, and speed make something. How is the Soft Skill in Malaysia, Ministry of Education has compiled various strategic and educational programs to ensure teachers and lecturers can develop and build a Soft Skill in each student's self. According to Azam (2007) The application and construction of Soft Skill was done in school level, technical and vocational training centre, higher learning institution, colleges and the private sector. These programs have been carried out by both stages to form students who are not only excellent in academics but also excellent Its appearance in various Soft Skill. Teachers and prospective teachers in educational institutions are given training and courses to implement and develop Soft Skill in students. Subjects and teaching of learning carried out such as history, life skills and co-curricular activities are given attention by the Ministry of Education to ensure the applicability and construction of Soft Skills take place in school. According to Uminadha (2011), the concept of Soft Skill was introduced by the Ministry of Education in several subjects as well as programs conducted in the school. According to Nor Hayati fatmi (2010) Soft Skills was applied in KBSR system and KBSM which was later extended to the Higher education center. This Soft Skills is applied by teachers whether during the teaching and learning process or while conducting co-curricular activities. This application occurs directly and indirectly.

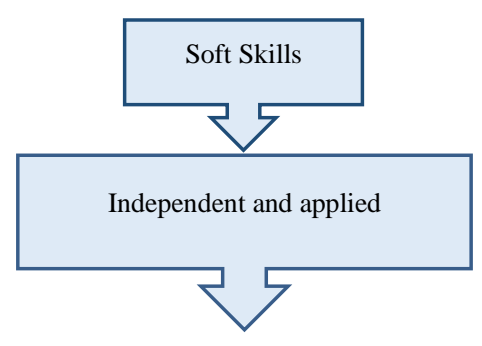




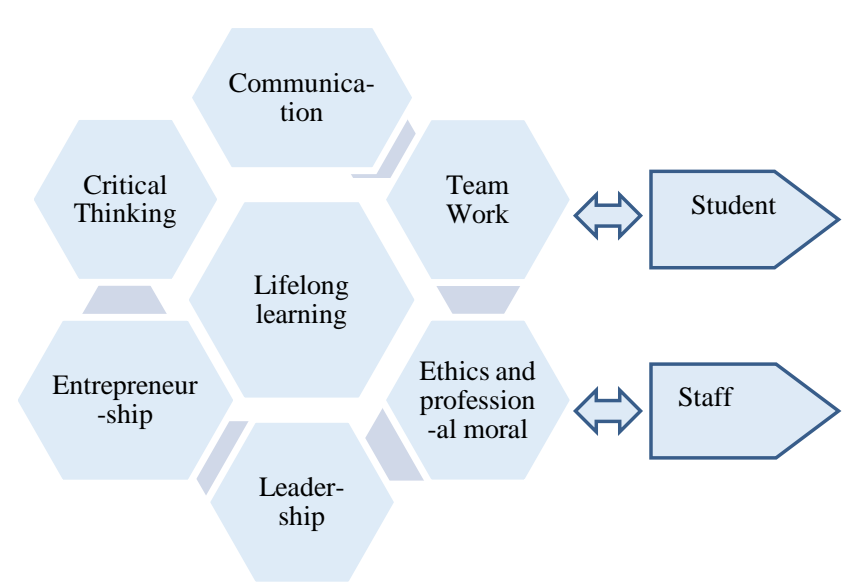

\section{DIAGRAM 3 Concepts of Seven Soft Skills Elements}

This study will attempt to rip the seven elements of Soft Skills, how the teaching and learning activities are based on the diversity of teaching creativity by following theories and distance models. And learning that has been described can help towards improving the Soft Skill of students. The seven elements of Soft Skills will be to discuss, how it will be applied during the teaching and learning process to build Soft Skill s students of history especially Master of Education (historical education).

\subsection{Detail Element Soft Skills}

It is supposed that every institution such as schools and IPTA in Malaysia should apply all seven elements of Soft Skill based on the details below. All these soft skill elements are adaptation and modified from the soft Skill Development module for Malaysian Higher education Institution (KPT, 2006).

\subsection{Communication Skills (Communication skills (CS))}

Communicating skills involve effective communication in Malay and English language in different contexts with different communication participants. Three povertybased descriptions are as follows.

\begin{tabular}{|c|l|}
\hline Stage & \multicolumn{1}{|c|}{ Proficiency } \\
\hline CS1 & $\begin{array}{l}\text { Ability to convey ideas clearly, } \\
\text { effectively and confidently, verbally } \\
\text { and in writing. }\end{array}$ \\
\hline CS2 & $\begin{array}{l}\text { Ability to practice active listening skills } \\
\text { and give feedback. }\end{array}$ \\
\hline CS3 & $\begin{array}{l}\text { The ability to make a clear } \\
\text { presentation, confidence and fit with } \\
\text { the listener level. }\end{array}$ \\
\hline
\end{tabular}

\subsection{Critical Thinking and problem Solving (CTPS)}

The thinking skills and problem-solving skills (CTPS) involve the ability to think critically, creatively, innovative, analysis, and ability to apply understanding and knowledge to new and different problems. Description Three skills CTPs are as follows:

\begin{tabular}{|c|l|}
\hline Stage & \multicolumn{1}{c|}{ Proficiency } \\
\hline CTPS1 & $\begin{array}{l}\text { Ability to identify and analyses } \\
\text { problems in complex and blurred } \\
\text { situations, and make judgments } \\
\text { justifying. }\end{array}$ \\
\hline CTPS2 & $\begin{array}{l}\text { Ability to expand and repair thinking } \\
\text { skills such as explaining, analyzing } \\
\text { and assessing discussions }\end{array}$ \\
\hline CTPS3 & $\begin{array}{l}\text { Ability to look for ideas and find } \\
\text { alternative solutions }\end{array}$ \\
\hline
\end{tabular}

\subsection{Team Work Skills (TS)}

Teamwork skills (TS) involve the ability to collaborate with others from various socio-cultural backgrounds to achieve the same goal. The three levels of skills of the TS are as follows:

\begin{tabular}{|l|l|}
\hline Stage & \multicolumn{1}{|c|}{ Proficiency } \\
\hline TS1 & $\begin{array}{l}\text { Ability to foster good relationships } \\
\text { interact and work effectively together to } \\
\text { achieve the same objectives }\end{array}$ \\
\hline TS2 & $\begin{array}{l}\text { Ability to understand and take a changing } \\
\text { role between group leaders and group } \\
\text { members. }\end{array}$ \\
\hline TS3 & $\begin{array}{l}\text { Ability recognizes and respects the } \\
\text { attitudes, behavior, and beliefs of others. }\end{array}$ \\
\hline
\end{tabular}

3.4. Continuous Learning and information management (Lifelong Learning and information Management) (LL)

Continuous learning (LL) involves an independent learning effort in the acquisition of new skills and knowledge. The two-level LL caption is as follows:

\begin{tabular}{|c|l|}
\hline Stage & \multicolumn{1}{|c|}{ Description } \\
\hline LL1 & $\begin{array}{l}\text { Ability to search and manage relevant } \\
\text { information from multiple sources. }\end{array}$ \\
\hline LL2 & $\begin{array}{l}\text { The ability to receive new ideas and be } \\
\text { able to take autonomy learning. }\end{array}$ \\
\hline
\end{tabular}

\subsection{Entrepreneurship Skills) (ES)}

Entrepreneurial skills (ES) involve the ability to explore opportunities and develop awareness about risks (risk 
Awareness), creativity and innovation in business and employment related activities. The three LEVELS of ES are as follows:

\begin{tabular}{|c|l|}
\hline Stage & \multicolumn{1}{|c|}{ Description } \\
\hline ES1 & Ability to identify business opportunities. \\
\hline ES2 & Ability to formulate business planning \\
\hline ES3 & $\begin{array}{l}\text { Ability to build, explore and seize } \\
\text { business and employment opportunities. }\end{array}$ \\
\hline
\end{tabular}

\subsection{Ethics and Professional Morals (EM)}

Ethics and moral Professionals (EM) involve ability to practice high moral standards in professional practice and social interactions. Here is the description for the EM stages are as follows:

\begin{tabular}{|c|l|}
\hline Stage & \multicolumn{1}{c|}{ Description } \\
\hline ET1 & $\begin{array}{l}\text { The ability to understand economic, } \\
\text { environmental and socio-cultural } \\
\text { impacts in professional practice. }\end{array}$ \\
\hline ET2 & $\begin{array}{l}\text { Ability to analyse and make decisions } \\
\text { about ethical issues. }\end{array}$ \\
\hline
\end{tabular}

\subsection{Leadership Skills) (LS)}

Leadership Skills (LS) involve the ability to practise the leadership traits, various activities. LS stage description is as follows:

\begin{tabular}{|c|l|}
\hline Stage & \multicolumn{1}{|c|}{ Description } \\
\hline LS1 & $\begin{array}{l}\text { Knowledge of the principle theory of } \\
\text { leadership. }\end{array}$ \\
\hline LS2 & Ability to lead the project. \\
\hline LS3 & $\begin{array}{l}\text { Ability to understand and take the role of } \\
\text { change between team leaders and team } \\
\text { members. }\end{array}$ \\
\hline
\end{tabular}

The method of implementing Soft Skills among students of history in the teaching and learning process can Implemented using standalone subject and applied (Embedded) models in the curriculum Academic and non - academic. Both Models explained such as following:

\subsubsection{Stand Alone Subject Model}

The independent subjects applied by most schools and IPT are in the category of Terrace subjects which meet the seven element Soft Skills such as Proficiency Entrepreneurship, Proficiency Think Creatives, Ethic and Moral, Proficiency Communicating and a so on. Among the self - reliant subjects are the subjects of entrepreneurial principles, Proficiency Its efficacy, historical skills, English language, and Malay language. Thus, students who take the subject will be applied to Soft Skills elements directly. Instructional history able to
Boost Soft Skills Learners History with an enforce Proficiency Thinking history. According to Baharuddin (2006) in the study, the teacher has been implementing the poverty of historical thought in thein the Instructional they had however Stage implementation of a very differ Follow category Thinking History. Learners History need to be mastered Thinking History such as Proficiency chronology, Proficiency Explore, Proficiency Interpretation, Proficiency Imagination and a Proficiency Rationalization to do Boost Soft Skills. According to Chowen (2005) declaring every teacher who teaches in historical subjects needs to be willing and understand the appropriate methods of teaching based on historical thinking. Thinking History, a very want to apply it was must to the direction boost Soft Skills Self learner's history.

\subsubsection{Applied Model (Embedded)}

Applied models employ the approach that implements the Soft Skills across the curriculum on teaching activities and a Learning for the lessons which in following Model, these does not require a Learners follows Lessons Special such as very expressed in the Lessons Self-Reliant. Instead, students trained to do mastered Soft Skill through activities Instructional and A Learning the formal design implemented Follow Methods certain without any Change and a reduce content of and a result learning a very need to be accomplished (KPT, 2006). Applied Soft Skills may do through Five Methods Submission of it, lectures, studies, viva, work laboratory and a work batch.

\subsubsection{Soft Skill Guru and Universities' Staff}

According to Nadler and Leonard, (1963) training is often associated with enhancing employee performance through enhanced knowledge, skills, self-esteem, ethics and attitude changes. Work outs needed by someone for acquiring knowledge and skills beginners as soft skill to enhance skills and knowledge available.

\section{Discussion}

Educators such as teachers and lecturers as human capital have the responsibility to ensure that Soft Skills can be applied and built in students especially students who take up history for the future of the student own. In accordance with Zainudin, (2005) the teacher must ensure that they are not only as a presenter of knowledge and provide information, but also responsible in guiding students to apply knowledge received in daily life them. Teachers should also use appropriate strategies to unify Soft Skills with an approach to teaching teacher learning 
with appropriate skills to be applied to their students. The application and construction of Soft Skills as well as academic teaching is to ensure that students use them in a life that is increasingly a change in the current globalization. Thus, students can avoid themselves from unhealthy symptoms such as drug abuse, skipping the school, run away from home and so on. In Accordance with Musliha (2011) The application of Soft Skills directly and indirectly to the student can be executed through a systematic curriculum, Teaching and learning methodology and co-curricular activities. According to Sarimah (2011) Soft Skill to students is through specific subjects such as entrepreneurship, life, and History and Geography skills. Entrepreneurial skills for example should be owned by students of Primary or tertiary studies. The situation is capable in producing human capital that can preserve the economic, social and political stability of the country. It is also able to make the human capital have a high and resilient competitive force.

\section{Research Methodology}

This study uses survey research methodology using the data collection method in an interview. Demographic surveys area Sekolah Kebangsaan Biah Batu 65 Beaufort, Sabah. A total of 14 teachers were taught at sekolah Kebangsaan Biah Batu 65 in 2019. A total of 3 teachers were made a sample study in an interview to obtain data on the implementation of Soft Skills in the teaching and learning they had made. An interview session was started on understanding the sample study on Soft Skills.

\subsection{Data Analysis}

Data analysis uses the schedule and uses the 'yes ' and ' no ' answers.

\begin{tabular}{|c|l|c|c|c|}
\hline No. & \multicolumn{1}{|c|}{$\begin{array}{c}\text { Interview } \\
\text { questions }\end{array}$} & $\begin{array}{c}\text { Sample } \\
\mathbf{1}\end{array}$ & $\begin{array}{c}\text { Sample } \\
\mathbf{2}\end{array}$ & $\begin{array}{c}\text { Sample } \\
\mathbf{3}\end{array}$ \\
\hline 1 & $\begin{array}{l}\text { Knowledge of } \\
\text { soft skills }\end{array}$ & Yes & Yes & Yes \\
\hline 2 & $\begin{array}{l}\text { Knowledge of } \\
\text { teaching theory }\end{array}$ & Yes & Yes & Yes \\
\hline 4 & $\begin{array}{l}\text { Does it always } \\
\text { use the } \\
\text { teaching theory } \\
\text { to improve soft } \\
\text { skills? }\end{array}$ & Yes & Yes & Yes \\
\hline $\begin{array}{l}\text { Knowing the } \\
\text { interests of soft } \\
\text { skills in } \\
\text { student life. }\end{array}$ & Yes & Yes & Yes \\
\hline
\end{tabular}

\begin{tabular}{|c|l|c|c|c|}
\hline 5 & $\begin{array}{l}\text { Ever attended a } \\
\text { course on how } \\
\text { to increase soft } \\
\text { skills? }\end{array}$ & Yes & Yes & No \\
\hline
\end{tabular}

The data analysis is conveyed easily through an interview run on top of three samples.

\subsection{Respondents Demographic}

Respondents' Demography is consisting of 2 female teachers and 1 male teacher at Sekolah kebangsaan Biah Batu 65 Beaufort Sabah. Females Teacher aged 36 years old and male teacher aged 48 years old and is a teacher who has been long ago served in the SK. Biah Batu 65 Beaufort Sabah. Interview is executed during no period airy teachers.

\subsection{Research Implications}

The implications of this study are very useful for historical teachers and other subjects to increase soft skills among their students. Various teaching and learning strategies that are based on the theories of teaching and learning that can be used to improve the soft skills students. This study also applies to students of IPT who study the field of teaching and learning towards improving Soft Skills.

\section{Conclusion}

Studies on the diversity of creative teaching and learning and how it can improve soft skill student history is important to run. Soft skills are very important for a country that wants to progress not only infrastructure development but the human capital development of the population as a whole. With soft skills students will not be drifted with the challenges of life in the future that are always challenging. Application Soft Skills to historical students allow the students to compete in the ready job market and innovate build and create work in the future.

\section{References}

[1] Noraini Idris (1987) second Edition. Research in Education. Includes bibliographical references and index. ISBN 978-967-5771-74-3.

[2] Huzili Bin Hussin. To strengthen Engineering students through the application of soft skills . 2015. Centre for communication and entrepreneurship skills, Universiti Malaysia Perlis.

[3] Mohd hairil Yaakup. 2016. Application and construction of soft skills in school. 
[4] Irfan Wanata.2010.Theory of Learning.Education of Computer Science. 